\title{
Pengembangan Media Pembelajaran Articulate Storyline Menggunakan Model Think Pair Share di Kelas IV Sekolah Dasar
}

Indah Firdawela

Jurusan PGSD Universitas Negeri Padang

firdawelaindah@gmail.com

Reinita

Jurusan PGSD Universitas Negeri Padang

reinita1652@fipunp.ac.id

\begin{abstract}
This research is develop an Articulate Storyline learning media using Think Pair Share model was valid and practical. This research was Research and Development. The development procedure uses the ADDIE model consisting of analysis, design, development, implementation, and evaluation. The instrument used was a validity questionnaire and a practicality questionnaire. Data collection techniques used qualitative and quantitative techniques. The results of this study are in the form of learning media produced from the Articulate Storyline application which has an attractive appearance for elementary school students. Based on the results of media validator get $76.5 \%$ a very valid category. material validator get $91 \%$ a very valid category, linguists validator get $100 \%$ a very valid category. The practicality of the teacher's response at SDN 22 Pasaman get $91.6 \%$ a very practical category and the practicality level at SDN 26 Pasaman get $95.8 \%$ a very practical category. The practicality of the students' responses at SDN 22 Pasaman get $91 \%$ a very practical category and the practicality level at SDN 26 Pasaman get $93.8 \%$ a very practical category. It can be concluded that the Articulate Storyline learning media is valid and practical.
\end{abstract}

Keyword: $R \& D$, Articulate Storyline, TPS

\section{Pendahuluan}

Media pembelajaran dalam proses pembelajaran perlu digunakan agar peserta didik dapat dengan mudah menyerap informasi dari pembelajaran. Media pembelajaran adalah alat yang membantu pendidik dalam proses pembelajaran. Sebagaimana Kustandi dan Sutjipto (2011) mengungkapkan bahwa media pembelajaran adalah sebuah alat yang dapat membantu proses pembelajaran dan memiliki fungsi sebagai memperjelas makna sebuah pesan yang disampaikan oleh guru, sehingga dapat mencapai tujuan pembelajaran dengan lebih baik dan sempurna. Alat yang dapat membantu pendidik membuat media pembelajaran yaitu dengan memanfaatkan perkembangan teknologi. Peran dari media pembelajaran yang berbasis teknologi ini dapat menarik perhatian peserta didik dalam penyampaian materi pembelajaran sehingga peserta didik antusias dalam mengikuti pembelajaran.

Pemanfaatan teknologi dalam pembelajaran tertuang dalam prinsip pembelajaran yang sesuai dengan Standar Kompetensi Lulusan dan Standar isi pada Peraturan Menteri Pendidikan dan Kebudayaan Nomor 22 tahun 2016 yaitu untuk meningkatkan efisiensi dan efektivitas pembelajaran yang berkelanjutan, guru dapat memanfaatkan teknologi, informasi dan komunikasi sesuai dengan situasi dan kondisi. Sehingga pencapaian tujuan pembelajaran yang menggunakan teknologi ini ideal. Dengan perkembangan teknologi ini diharapkan mampu melahirkan peserta 
didik yang dapat kolaboratif, komunikatif, berpikir kritis, kreatif dan inovatif yang sesuai dengan tantangan pembelajaran abad 21 yang disebut dengan kompetensi 4C. Perkembangan teknologi menghasilkan bermacam-macam kemudahan salah satuya aplikasi perangkat lunak yang dapat digunakan dalam membuat media pembelajaran. Salah satu aplikasi perangkat lunak tersebut yaitu Articulate Storyline. Sebagaimana Darnawati, Jamaludin, Batia, Irawaty dan Salim (2019) mengemukakan bahwa media pembelajaran menggunakan Articulate Storyline diharapkan mampu menjadi alternatif media pembelajaran yang dapat menghadirkan suasana pembelajaran baru dan menarik serta mampu membantu pendidik menyampaikan materi yang sulit untuk disampaikan. Media pembelajaran menggunakan Articulate Storyline ini menghasilkan media pembelajaran yang menyampaikan materi pembelajaran dengan kombinasi dari gambar, slide, video, audio, dan animasi sehingga pembelajaran lebih menarik dan juga bisa menjadi sarana untuk melakukan tes atau kuis secara interaktif. Darnawati, et., al. (2019) mengungkapkan aplikasi Articulate Storyline merupakan software yang diluncurkan pada tahun 2014 oleh Global Incorporation yang digunakan untuk membuat media pembelajaran yang interaktif, software ini memiliki kemampuan untuk dapat menggabungkan slide, flash (swf), video, dan karakter animasi menjadi satu. Software ini telah tersedia dalam format .exe sehingga bisa digunakan langsung pada PC/laptop dan tidak menginstal ulang. Software ini dapat di jalankan pada windows 7,8 dan 10 .

Rianto (2020) menyebutkan bahwa penggunaan perangkat lunak ini seperti layaknya membuat pembelajaran power point namun dikombinasikan dengan fungsi trigger tanpa pengkodean yang mudah digunakan untuk memfungsikan tomboltombol navigasi. Oleh karena itu penggunaan dan pembuatan media pembelajaran menggunakan Articulate Storyline ini mudah dan dapat dijadikan solusi dalam membuat media pembelajaran yang menarik dan kreatif. Sejalan dengan itu Rafmana, Chotimah, dan Alfiandra (2018) menyatakan bahwa jika pemanfaatan dalam penggunaan media Articulate Storyline ini secara tepat dapat menjadi pembangkit motivasi dan rangsangan terhadap proses pembelajaran peserta didik. Selain itu media pembelajaran Articulate Storyline juga bermanfaat sebagai media dalam menambah dan memperluas pengetahuan di dalam pembelajaran yang memberi informasi akurat dan terbaru, sehingga dapat membantu peserta didik dalam bersikap, berpikir, dan berkembang lebih lanjut serta memberi motivasi yang tinggi.

Kelebihan Articulate Storyline sebagaimana yang diungkapkan oleh Nabilah, Sesrita, dan Suherman (2020) aplikasi Articulate Storyline ini merupakan aplikasi multimedia interaktif yang dapat digunakan oleh guru dan peserta didik. Aplikasi ini mirip dengan PowerPoint sehingga mudah mengaplikasikannya. Untuk menggunakannya Articulate Storyline ini bisa dipublikasikan sesuai keinginan penggunanya. Aplikasi ini dapat diakses melalui internet karena didukung dalam format HTML5 dan juga dapat diakses melalui komputer dan smartphone. Selain itu Rohmah dan Bukhori (2020) mengungkapkan media pembelajaran menggunakan Articulate Storyline memiliki beberapa kelebihan yaitu sebagai berikut 1) aplikasi yang dapat dipublikasikan ke playstore, 2) tampilan yang diberikan interaktif, 3) memudahkan peserta didik belajar dimana saja dan kapan saja, 4) dapat diakses secara offline, 5) media pembelajaran yang bisa digunakan di rumah.

Dalam pelaksanaan pembelajaran selain penggunaan media pembelajaran, penggunaan model pembelajaran juga berperan dalam keterlaksanaan pembelajaran. Model pembelajaran ini berguna untuk menghasilkan pembelajaran yang terarah dan menyenangkan agar peserta didik tidak merasa bosan dalam pembelajaran dan bisa lebih bersemangat lagi. Salah satu model pembelajaran berkelompok dapat diterapkan dalam proses pembelajaran yaitu model pembelajaran 
Think Pair Share (TPS). Model TPS adalah sebuah model pembelajaran kelompok yang di dalam pelaksanaannya peserta didik akan berpikir sendiri dan bekerja sama dengan peserta didik lain melalui kelompoknya. Sebagaimana Murti dan Reinita (2020) menyatakan bahwa TPS merupakan model pembelajaran kelompok yang disusun untuk mempengaruhi ragam hubungan antar peserta didik. Melalui penggunaan model TPS ini peserta didik dapat meningkatakan kerja sama antar sesamanya dan meningkatkan kemampuan peserta didik dalam mengemukakan pendapatnya. Sejalan dengan itu Reinita dan Andrika (2017) menyatakan bahwa setelah menerapkan model TPS dalam proses pembelajaran maka peserta didik akan aktif dalam berpikir karena model ini dapat memaksimalkan hasil belajar peserta didik.

Menurut Huda dalam U'la, Murtono dan Ulya (2018) TPS memiliki keunggulan dalam praktiknya, diantaranya (1) peserta didik selain bekerja bersama kelompok juga ada bekerja sendiri (2) meningkatkan keaktifan peserta didik dalam belajar (3) peserta didik diberi kesempatan untuk bisa mengkomunikasikan hasil pemikirannya dengan peserta didik lain. Selain itu, menurut Prahl (2017) kelebihan-kelebihan yang dimiliki model TPS ialah 1) mudah digunakan dengan berbagai cara di kelas; 2) peserta didik selain melakukan kegiatan individu juga melakukan kegiatan dengan pasangannya; 3) meningkatkan keterlibatan dan pemahaman peserta didik; 4) memberikan kesempatan kepada peserta didik untuk mempraktikkan keterampilan dalam berkomunikasi dan memecahkan masalah; 5) peserta didik dapat menemukan pemecahan masalah dari banyak pendapat.

Langkah-langkah pelaksanaan model pembelajaran TPS menurut Huda dalam Fathurrohman (2015) sebagai berikut: (1) Thinking, pada tahapan ini melalui penayangan media Articulate Storyline guru akan mengajukan beberapa pertanyaan atau isu yang berhubungan dengan permasalahan yang akan di pelajari dan peserta didik diberi waktu untuk memikirkan jawaban dari pertanyaan isu-isu tersebut secara mandiri. (2) Pairing, tahap selanjutnya Pair yaitu peserta didik nantinya akan di kelompokkan secara berpasangan untuk mendiskusikan apa yang telah dipikirkannya secara mandiri pada tahap sebelumnya. Pada tahap ini diharapkan terjadinya interaksi anatara peserta didik untuk menemukan jawaban atas pertanyaan isu-isu yang telah di berikan. (3) Sharing, setelah peserta didik di pasangkan di tahap sebelumnya dan menemukan jawaban dari isu-isu tersebut lalu peserta didik diminta untuk menyampaikan hasil jawabannya untuk berbagi dengan seluruh kelas. Hal ini di lakukan secara bergiliran hingga seperempat dari pasangan. Setelah beberapa pasang peserta didik menyampaikan hasil diskusinya, lalu guru akan memberikan penegasan melalui penayangan media Articulate Storyline.

Berdasarkan wawancara yang dilakukan bersama wali kelas IV ditemukan kekurangan-kekurangan yaitu masih minim dalam penggunaan media pembelajaran, kurangnya pengetahuan pendidik dalam menggunakan aplikasiaplikasi untuk membuat media pembelajaran yang menarik, kurang memanfaatkan alat-alat yang menggunakan teknologi dalam mengajar, pendidik sesekali melihatkan contoh materi pembelajaran dari youtube melalui laptop sebagai media pembelajarannya, kurangnya semangat motivasi dalam pembelajaran karena pembelajaran yang kurang menyenangkan, peserta didiknya masih pasif dalam pembelajaran, pendidik dalam melakukan langkah pembelajaran kurang menggunakan model pembelajaran yang bervariasi.

Melihat kekurangan-kekurangan yang ada di lapangan dan membutuhkan pembaharuan dalam proses pembelajaran. Sebagaimana kemajuan dalam pendidikan yang sudah dipaparkan di atas maka dalam penelitian ini dikembangkan sebuah media pembelajaran yang menggunakan aplikasi Articulate Storyline dengan 
model pembelajaran TPS pada pembelajaran tematik terpadu di tema 7 subtema 1 pada kelas IV Sekolah Dasar. Tujuan dari penelitian ini ialah mengembangkan Media Pembelajaran Articulate Storyline menggunakan Model TPS pada Tema 7 Subtema 1 di Kelas IV Sekolah Dasar yang valid dan praktis. Dengan spesifikasi produk yang diharapkan yaitu media pembelajaran Articulate Storyline menggunakan Model TPS pada tema 7 subtema 1 yang menarik, serta media pembelajaran Articulate Storyline menggunakan Model TPS yang memuat video, gambar, teks, animasi dan kuis yang menarik untuk anak-anak usia SD sesuai dengan materi pembelajaran.

\section{Metode}

Penelitian media pembelajaran Articulate Storyline menggunakan jenis penelitian Reseach and Development (R\&D) dengan model pengembangan ADDIE. Metode penelitian pengembangan (R\&D) menurut Hamzah (2019) ialah sebuah penelitian yang digunakan untuk menghasilkan suatu produk dan di uji hasil penggunaannya. Tujuan akhir dari metode peneliatian pengembangan (R\&D) di bidang pendidikan adalah melahirkan suau produk baru atau menyempurnakan suatu produk yang sudah ada untk meningkatkan kualitas dari pendidikan dan diharapkan proses pendidikan menjadi lebih efektif dan sesuai kebutuhan dilapangan. Tahapan model ADDIE ini ada 5 yaitu: (1) Analysis (analisis), langkah analisis terdiri dari dua tahap, yaitu analisis kinerja dan analisis kebutuhan. Analisis kerja untuk mengetahui dan mengelompokkan masalah yang ada. Analisis kebutuhan untuk menentukan solusi dari permasalahan yaitu media pembelajaran menggunakan Articulate Storyline; (2) Design (perencanaan) tahap ini berupa a) menentukan dan merancang instrumen yang digunakan yaitu berupa angket untuk validator dan praktisi. b) merancang produk yang dikembangkan dengan meninjau materi pembelajaran yang tepat untuk dikembangkan sesuai dengan media pembelajaran Articulate Storyline; (3) Development (pengembangan), pada tahap ini yaitu a) mengembangkan media pembelajaran yang telah dirancang. b) melakukan validasi produk oleh validator c) melakukan revisi produk. (4) Implementation (penerapan) merupakan tahap uji coba di lapangan untuk menerapkan produk yang telah dikembangkan berdasarkan masukan dari para ahli; dan (5) Evaluation (evaluasi) tahap ini adalah penilaian dari praktisi, yaitu guru kelas IV dan peserta didik kelas IV untuk mengetahui kualitas produk yang dikembangkan.

Data yang didapatkan dari penelitian ini adalah data kualitatif dan kuantitatif. Data kualitatif di dapatkan dari hasil angket yang berupa saran dan masukan dari subjek uji coba penelitian. Data kuantitatif di dapatkan dari angket yang berupa nilai angka. Produk yang dikembangkan ini di uji kevalidannya dan kepraktisannya menggunakan alat penelitian berupa angket. Untuk menguji kevalidannya dilakukan oleh ahli media, ahli materi dan ahli bahasa. Ahli ini adalah dosen yang berada di bidangnya. Untuk menguji kepraktisan produk ini, di nilai oleh praktisi di dua sekolah uji coba yaitu sekolah pertama di SDN 22 Pasaman satu orang guru wali kelas IV dan 14 orang peserta didik kelas IV, sekolah kedua di SDN 26 Pasaman satu orang guru wali kelas IV dan 17 orang peserta didik kelas IV.

Data hasil dari validasi dan praktikalisasi yang diperoleh akan dianalisis terhadap seluruh aspek yang disajikan dalam berbentuk tabel dengan menggunakan skala likert yaitu berupa nilai dari 1 sampai 4 . Dibagi atas 4 tingkatan yaitu 4 (sangat baik), 3 (baik), 2 (kurang baik), 1 (sangat tidak baik).

Selanjutnya untuk mengukur perhitungan dan nilai akhir hasil validitas menggunakan rumus Arikunto dalam Pratama (2018: 25) yaitu: 


$$
P=\frac{\sum X}{N} \times 100 \%
$$

Keterangan:

$P \quad=$ persentase skor ahli

$\sum X=$ jumlah skor dari validator/praktisi

$N \quad=$ skor maksimal

Nilai akhir yang diperoleh akan dikonversikan ke dalam kategori validitas. Berikut kategori validitas media pembelajaran yang dimodifikasi dari Arikunto dalam Pratama (2018).

Tabel 1. Kategori Validitas dan Praktikalitas

\begin{tabular}{ccc}
\hline No & Kategori Validitas & Tingkat Validitas \\
\hline 1 & $75,01 \%-100,00 \%$ & Sangat Valid/Praktis \\
\hline 2 & $50,01 \%-75,00 \%$ & Valid/Praktis \\
\hline 3 & $25,01 \%-50,00 \%$ & Kurang Valid/Praktis \\
\hline 4 & $00,00 \%-25,00 \%$ & Sangat Tidak Valid/Praktis \\
\hline & & (Dimodifikasi dari Pratama, 2018)
\end{tabular}

\section{Hasil}

Produk Media Pembelajaran Articulate Storyline yang Dikembangkan Produk media pembelajaran Articulate Storyline yang dikembangkan dan digunakan di lapangan dapat dilihat bagiannya sebagai berikut.

\section{Tampilan memulai media pembelajaran}

Pada tampilan ini memperlihatkan tema, subtema dan pembelajaran yang akan dilaksanakan lalu memasukkan nama untuk bisa lanjut ke tampilan selanjutnya. Tertulis pada tampilan ini yaitu "Tema 7 Indahnya Keragaman Negeriku Subtema 1 Keragaman Suku Bangsa dan Agama di Negeriku Pembelajaran 3". "Tema 7 Indahnya Keragaman Negeriku Subtema 1 Keragaman Suku Bangsa dan Agama di Negeriku Pembelajaran 4". 'Tema 7 Indahnya Keragaman Negeriku Subtema 1 Keragaman Suku Bangsa dan Agama di Negeriku Pembelajaran 5”.

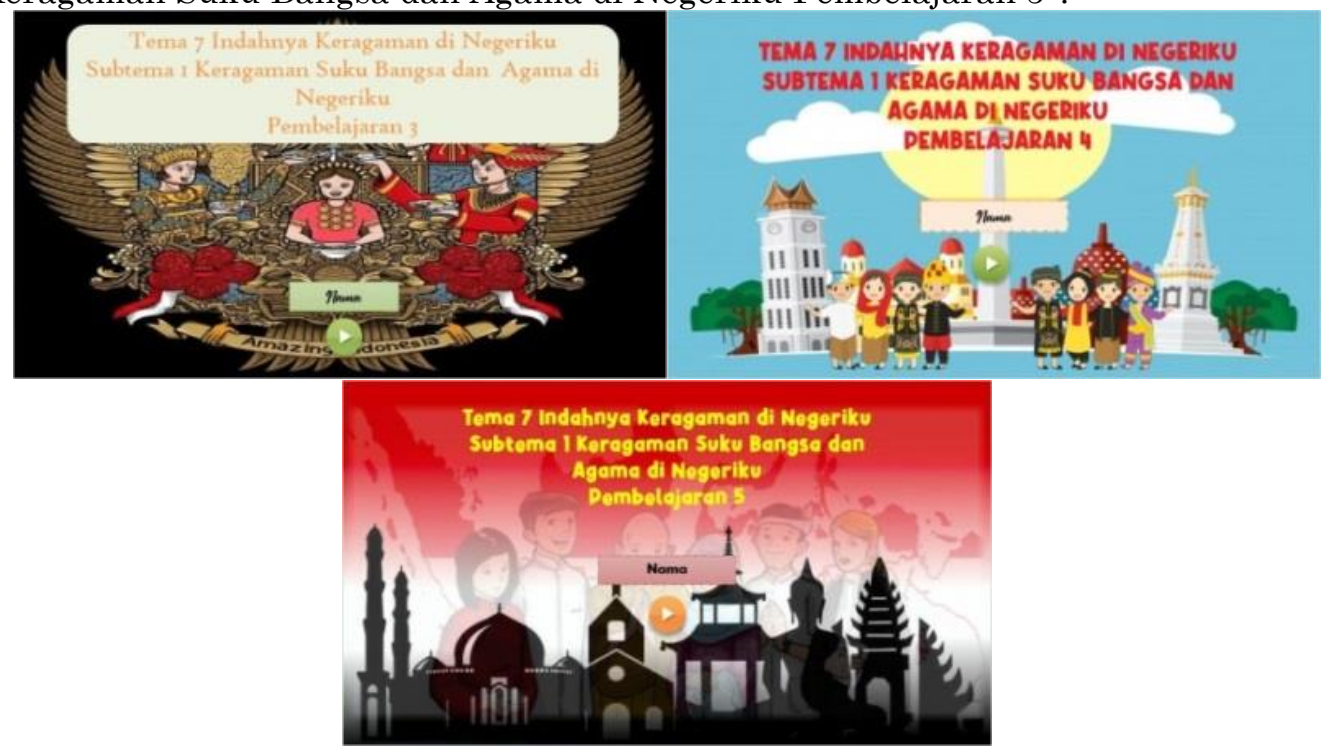

Gambar 1. Tampilan memulai media pembelajaran Articulate Storyline 


\section{Tampilan halaman utama}

Pada tampilan ini memperlihatkan kata sapaan untuk peserta didik dan terdapat pilihan untuk di klik sehingga bisa lanjut sesuai pilihan yang di klik yaitu ada KD dan indikator, materi, soal evaluasi, dan profil pengembang.

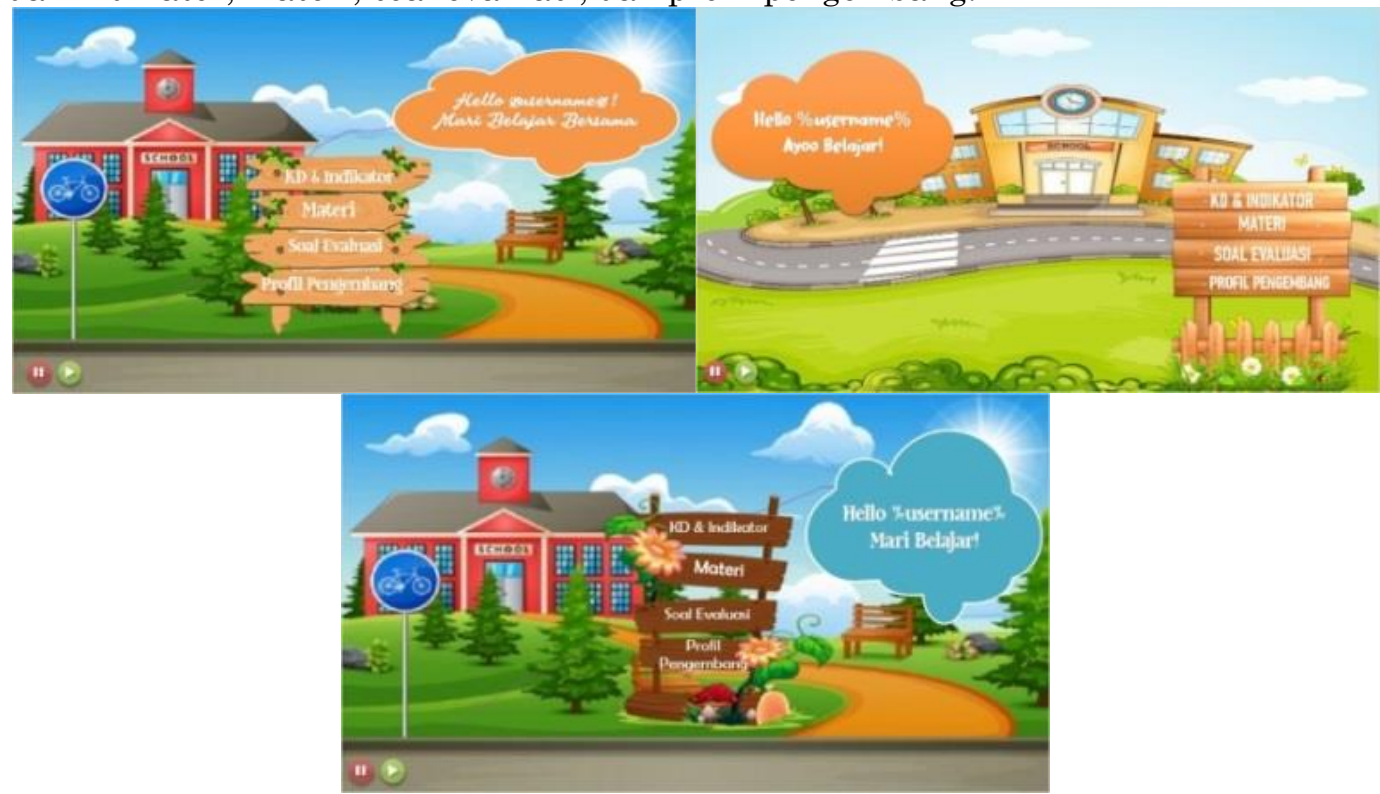

Gambar 2. Tampilan halaman utama media pembelajaran Articulate Storyline

\section{Tampilan Kompetensi Dasar (KD) dan Indikator}

Pada tampilan di bawah ini terdapat KD dan indikator sesuai materi pembelajaran pada tema, subtema, dan pembelajaran yang dilaksanakan. Tampilan ini akan mucul saat mengklik KD dan Indikator pada halaman utama. Dibawah ini salah satu tampilan yang ada pada media pembelajaran bagian KD dan indikator pada tiap pembelajaran.

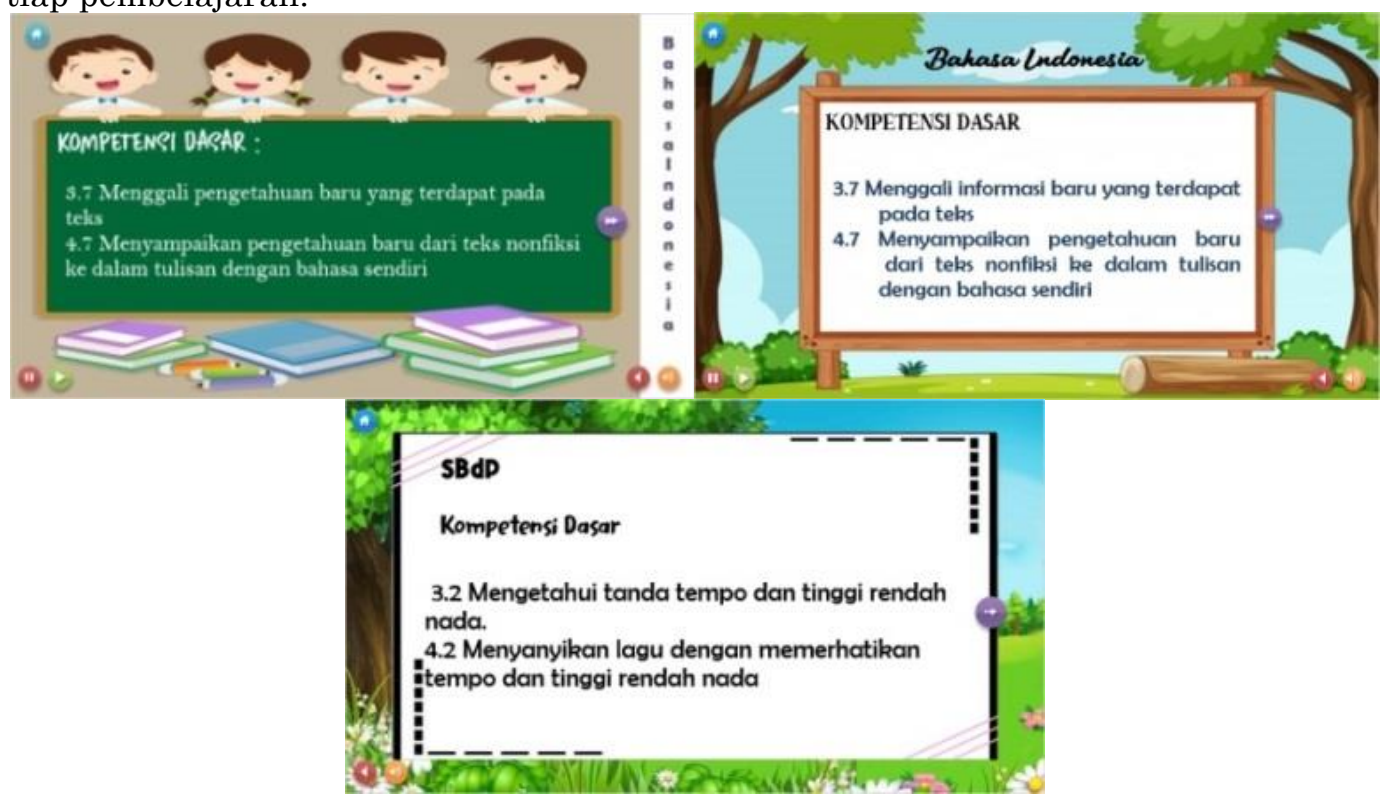

Gambar 3. Tampilan kompetensi dasar dan indikator

Tampilan materi pembelajaran

Pada tampilan ini terdapat materi pembelajaran yang dilaksanakan sesuai tema, subtema, dan pembelajaran. Di bawah ini merupakan salah satu tampilan materi pembelajaran pada media pembelajaran dari tiap pembelajaran. 


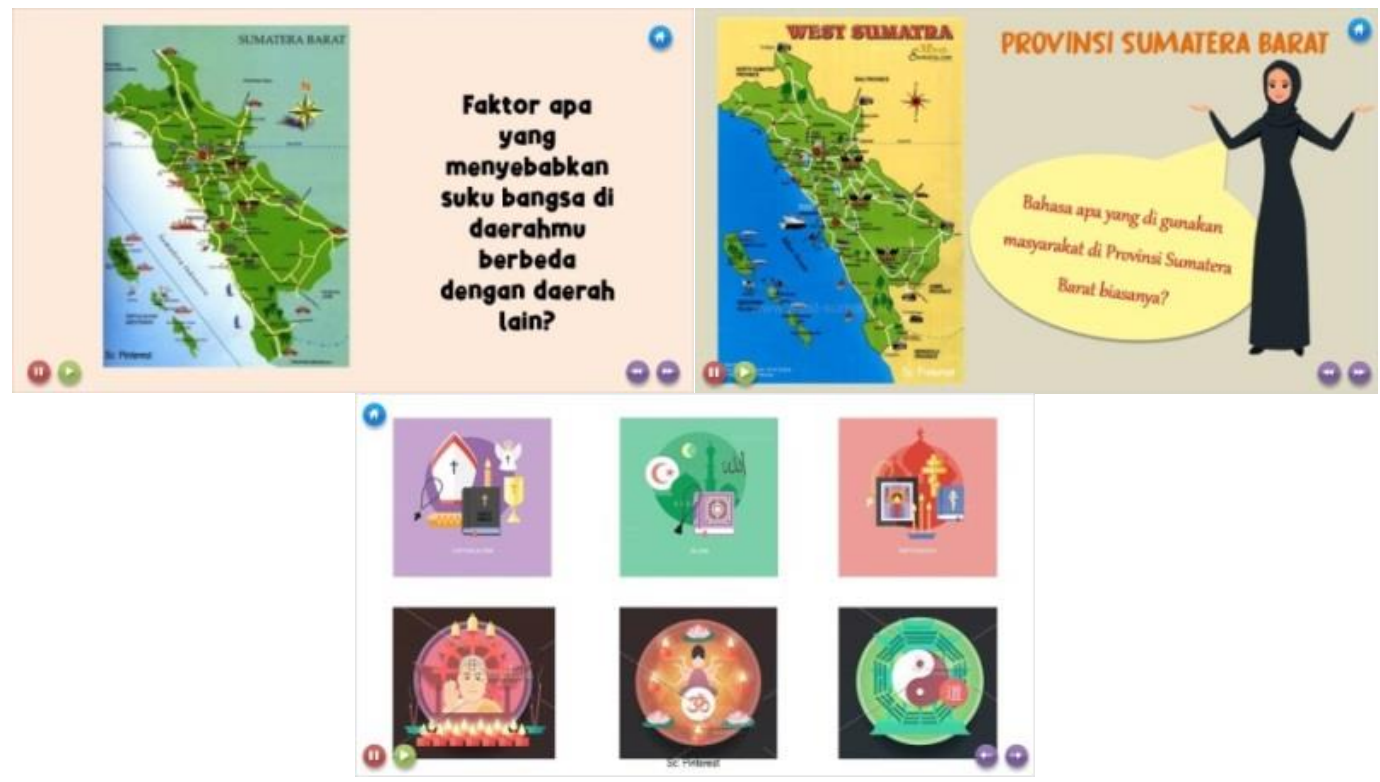

Gambar 4. Tampilan materi pembelajaran

Tampilan soal evaluasi

Pada tampilan ini terdapat soal evaluasi yang sesuai dengan pembahaasan materi pembelajaran. Dibawah ini merupakan salah satu tampilan soal evaluasi pada media pembelajaran dari tiap pembelajaran.

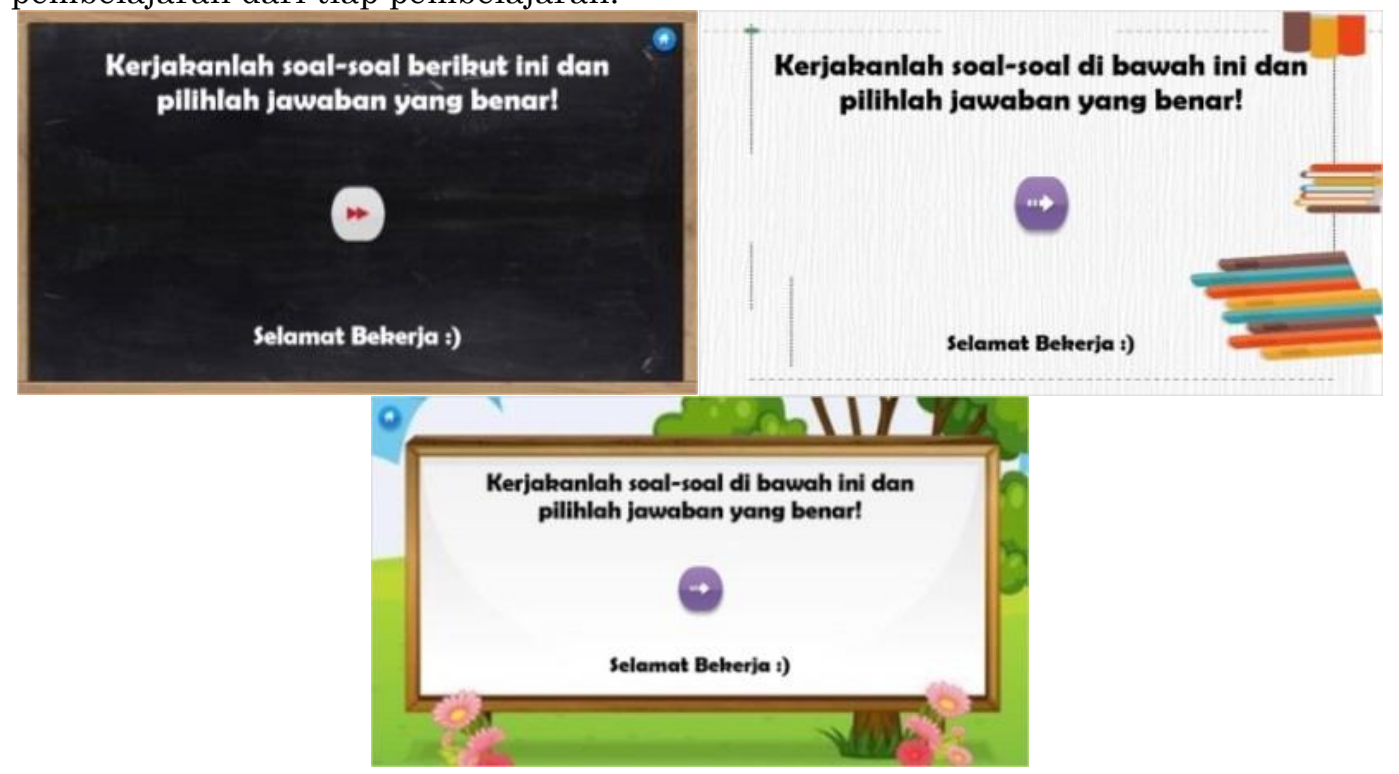

Gambar 5. Tampilan Soal Evaluasi

Tampilan profil pengembang

Tampilan ini adalah informasi mengenai pengembang media pembelajaran ini.

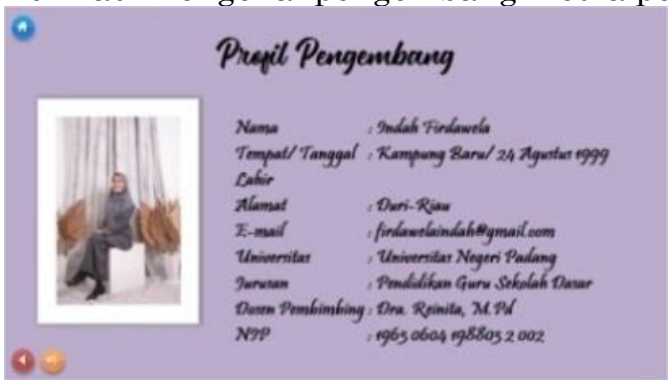

Gambar 6. Tampilan Profil Pengembang 


\section{Hasil Penilaian Validitas dan Praktikalitas}

Penilaian validitas media pembelajaran Articulate Storyline masing-masing dari validator ahli media, materi, dan bahasa dapat dilihat pada tabel berikut.

Tabel 2. Hasil Penilaiaan Validasi Media

\begin{tabular}{|c|c|c|c|}
\hline \multirow[b]{2}{*}{ No } & \multirow[b]{2}{*}{ Aspek yang Dinilai } & \multicolumn{2}{|c|}{ Penilaian } \\
\hline & & $\begin{array}{l}\text { Penilaian } \\
\text { I }\end{array}$ & $\begin{array}{l}\text { Penilaian } \\
\text { II }\end{array}$ \\
\hline \multirow[t]{4}{*}{1} & Mengajak peserta didik untuk belajar & 3 & 3 \\
\hline & $\begin{array}{l}\text { Kemampuan media dapat menciptakan rasa senang peserta } \\
\text { didik }\end{array}$ & 3 & 3 \\
\hline & $\begin{array}{l}\text { Tampilan gambar membuat peserta didik semangat untuk } \\
\text { belajar }\end{array}$ & 4 & 4 \\
\hline & Gaya tulisan komunikatif & 3 & 3 \\
\hline \multirow[t]{4}{*}{2} & Mendorong peserta didik untuk membaca & 3 & 3 \\
\hline & Menyampaikan maksud dan tujuan yang jelas & 2 & 3 \\
\hline & $\begin{array}{l}\text { Terjadinya komunikasi antara peserta didik dan media } \\
\text { pembelajaran }\end{array}$ & 2 & 3 \\
\hline & Menimbulkan rasa senang peserta didik untuk belajar & 3 & 3 \\
\hline \multirow[t]{4}{*}{3} & Tampilan yang digunakan menarik & 4 & 4 \\
\hline & Perpaduan warna tidak membosankan & 3 & 3 \\
\hline & Kreatif dalam menuangkan ide gagasan & 3 & 3 \\
\hline & Animasi dan gambar yang digunakan menarik & 3 & 3 \\
\hline \multirow[t]{4}{*}{4} & Sajian pembuka & 2 & 3 \\
\hline & Sajian Kompetensi Dasar dan indikator & 2 & 3 \\
\hline & Sajian Materi Pembelajaran & 2 & 3 \\
\hline & Sajian Soal Evaluasi & 3 & 3 \\
\hline \multirow[t]{4}{*}{5} & Kemenarikan media & 3 & 3 \\
\hline & Kesesuaian pemilihan background & 3 & 3 \\
\hline & Kesesuaian proporsi warna & 3 & 3 \\
\hline & Ketajaman gambar dan animasi & 2 & 3 \\
\hline \multirow[t]{4}{*}{6} & $\begin{array}{l}\text { Penempatan gambar dan keteranga tidak menganggu } \\
\text { pemahaman }\end{array}$ & 2 & 3 \\
\hline & $\begin{array}{l}\text { Penempatan kegiatan sebagai background tidak menganggu } \\
\text { judul, dan teks. }\end{array}$ & 3 & 3 \\
\hline & Penempatan animasi tidak menganggu pemahaman & 3 & 3 \\
\hline & Penempatan icon-icon tidak menganggu pemahaman & 3 & 3 \\
\hline \multirow[t]{4}{*}{7} & Gambar tidak menggaggu pemahaman & 3 & 3 \\
\hline & Gambar sesuai teks & 3 & 3 \\
\hline & Gambar yang digunakan sesuai dengan materi & 3 & 3 \\
\hline & Gambar jelas & 2 & 3 \\
\hline \multirow[t]{6}{*}{8} & Kesesuaian jenis huruf & 3 & 3 \\
\hline & Kesesuaian ukuran font & 3 & 3 \\
\hline & Keterbacaaan teks & 3 & 3 \\
\hline & Variasi ukuran dan jenis huruf & 3 & 3 \\
\hline & Jumlah yang Diperoleh & 90 & 98 \\
\hline & Skor Maksimal & 128 & 128 \\
\hline
\end{tabular}


Validasi oleh ahli media dilakukan sebanyak dua kali. Hasil perhitungan uji validitas untuk ahli media pada validasi pertama diperoleh persentase skor 70,3\% dengan kategori valid. Pada validasi kedua setelah melakukan revisi diperoleh persentase skor $76,5 \%$ dengan kategori sangat valid. Hasil uji validitas ahli media mengalami kenaikan dan menyatakan produk valid dan bisa di uji ke lapangan.

Tabel 3. Hasil Penilaian Validasi Materi

\begin{tabular}{|c|c|c|}
\hline No & Aspek yang Dinilai & Penilaian \\
\hline 1 & $\begin{array}{l}\text { Kesesuaian pokok bahasan media pembelajaran dengan materi tema } 7 \\
\text { subtema } 1 \text { pembelajaran } 3,4 \text {, dan } 5 \text { di kelas IV }\end{array}$ & 4 \\
\hline 2 & $\begin{array}{l}\text { Materi pada media pembelajaran disajikan sesuai dengan } \\
\text { perkembangan anak usia kelas IV Sekolah Dasar }\end{array}$ & 3 \\
\hline 3 & $\begin{array}{l}\text { Penyampaian materi pada media pembelajaran memenuhi kebutuhan } \\
\text { peserta didik kelas IV Sekolah Dasar }\end{array}$ & 4 \\
\hline 4 & $\begin{array}{l}\text { Kebenaran materi pembelajaran tema } 7 \text { subtema } 1 \text { pembelajaran } 3,4 \text {, } \\
\text { dan } 5 \text { kelas IV }\end{array}$ & 4 \\
\hline 5 & $\begin{array}{l}\text { Materi pada media pembelajaran dapat menambah wawasan dan } \\
\text { pengetahuan peserta didik }\end{array}$ & 3 \\
\hline 6 & $\begin{array}{l}\text { Materi pada media pembelajaran dapat dengan mudah dipahami oleh } \\
\text { peserta didik kelas IV }\end{array}$ & 4 \\
\hline 7 & Media pembelajaran sesuai dengan bahan ajar & 4 \\
\hline 8 & $\begin{array}{l}\text { Uraian penyajian materi pada media pembelajaran secara utuh dan } \\
\text { sistematis }\end{array}$ & 3 \\
\hline 9 & Pemilihan gambar-gambar yang sesuai dengan materi pembelajaran & 3 \\
\hline 10 & $\begin{array}{l}\text { Materi yang disajikan pada media pembelajaran menimbulkan respon } \\
\text { dari peserta didik }\end{array}$ & 4 \\
\hline 11 & Materi pada media pembelajaran disajikan secara lengkap & 3 \\
\hline 12 & $\begin{array}{l}\text { Penyajian materi disertai dengan evaluasi sebagai bahan latihan } \\
\text { peserta didik }\end{array}$ & 4 \\
\hline 13 & $\begin{array}{l}\text { Penyajian materi pada media pembelajaran menggunakan bahasa } \\
\text { yang komunikatif }\end{array}$ & 4 \\
\hline \multirow[t]{3}{*}{14} & Teks dan gambar dapat dibaca dengan jelas & 4 \\
\hline & Jumlah Skor & 51 \\
\hline & Skor Maksimal & 56 \\
\hline
\end{tabular}

Validasi oleh ahli materi dilakukan sebanyak satu kali. Hasil perhitungan uji validitas untuk ahli materi memperoleh persentase skor $91 \%$ dengan kategori sangat valid. Produk dinyatakan sudah bisa di uji ke lapangan.

Tabel 4. Hasil Penilaian Validasi Bahasa

No Aspek yang Dinilai

Penilaian

Penilaian I Penilaian II

\begin{tabular}{clcc}
\hline $\mathbf{1}$ & $\begin{array}{l}\text { Istilah yang digunakan tepat dan sesuai dengan } \\
\text { karakteristik peserta didik kelas IV SD }\end{array}$ & 3 & 4 \\
\hline $\mathbf{2}$ & $\begin{array}{l}\text { Kesesuaian dengan kaidah bahasa Indonesia yang } \\
\text { baik dan benar }\end{array}$ & 3 & 4 \\
\hline $\mathbf{3}$ & Penggunaan bahasa yang santun & 3 & 4 \\
\hline $\mathbf{4}$ & Bahasa yang digunakan efektif dan efisien & 3 & 4 \\
\hline & Jumlah Skor & $\mathbf{1 2}$ & $\mathbf{1 6}$ \\
\hline Skor Maksimal & $\mathbf{1 6}$ & $\mathbf{1 6}$
\end{tabular}

Validasi oleh ahli bahasa dilakukan sebnayak dua kali. Hasil perhitungan uji validitas untuk ahli bahasa pada validasi pertama diperoleh persentase skor $75 \%$ dengan kategori valid. Pada validasi kedua setelah melakukan revisi diperoleh 
persentase skor $100 \%$ degan kategori sangat valid. Hasil uji validitas ahli bahasa megalami kenaikan dan menyatakan produk valid dan bisa di uji ke lapangan.

Berikut penyajian hasil respon guru terhadap media pembelajaran Articulate Storyline.

Tabel 5. Hasil Praktikalias Respon Guru

\begin{tabular}{|c|c|c|c|}
\hline No. & Aspek yang Dinilai & $\begin{array}{c}\text { Penilaiaan } \\
\text { SDN 22 } \\
\text { Pasaman }\end{array}$ & $\begin{array}{l}\text { Penilaian } \\
\text { SDN 26 } \\
\text { Pasaman }\end{array}$ \\
\hline 1 & $\begin{array}{l}\text { Media memudahkan guru untuk menyampaikan } \\
\text { materi pada peserta didik }\end{array}$ & 4 & 4 \\
\hline 2 & $\begin{array}{l}\text { Bahasa yang digunakan pada media } \\
\text { sesuai dengan EYD }\end{array}$ & 3 & 3 \\
\hline 3 & Penyajian kalimat mudah dipahami oleh guru & 4 & 4 \\
\hline 4 & $\begin{array}{l}\text { Gambar dalam media pembelajaran memudahkan } \\
\text { guru membantu peserta didik memahami materi }\end{array}$ & 4 & 4 \\
\hline 5 & $\begin{array}{l}\text { Penempatan tata letak gambar atau ilustrasi yang } \\
\text { tepat sesuai dengan uraian materi }\end{array}$ & 3 & 4 \\
\hline 6 & $\begin{array}{l}\text { Media pembelajaran memudahkan guru untuk } \\
\text { menarik minat peserta didik dalam pembelajaran }\end{array}$ & 4 & 4 \\
\hline & Jumlah Keseluruhan & 22 & 23 \\
\hline & Skor Maksimum & 24 & 24 \\
\hline
\end{tabular}

Hasil uji praktikalitas respon guru di SDN 22 Pasaman memperoleh persentase skor 91,6\% dengan kategori sangat praktis. Hasil uji praktikalitas respon guru di SDN 26 Pasaman memperoleh persentase skor 95,8\% dengan kategori sangat praktis.

Berikut perhitungan hasil praktikalitas angket repon peserta didik SDN 22 Pasaman.

Tabel 5. Hasil Praktikalitas Respon Peserta Didik SDN 22 Pasaman

\begin{tabular}{lcccccccc}
\hline No & Responden & \multicolumn{4}{c}{ Responden Terhadap Pertanyaan } & \multirow{2}{*}{ Jumlah } \\
\cline { 2 - 7 } & & $\mathbf{1}$ & $\mathbf{2}$ & $\mathbf{3}$ & $\mathbf{4}$ & $\mathbf{5}$ & $\mathbf{6}$ & \\
\hline $\mathbf{1}$ & AFL & 1 & 4 & 1 & 1 & 4 & 3 & 14 \\
\hline $\mathbf{2}$ & AHS & 3 & 4 & 3 & 4 & 4 & 4 & 22 \\
\hline $\mathbf{3}$ & AI & 1 & 4 & 3 & 2 & 1 & 3 & 14 \\
\hline $\mathbf{4}$ & AMS & 4 & 4 & 4 & 4 & 4 & 4 & 24 \\
\hline $\mathbf{5}$ & BCL & 4 & 4 & 4 & 4 & 4 & 4 & 24 \\
\hline $\mathbf{6}$ & HYP & 4 & 4 & 4 & 4 & 4 & 4 & 24 \\
\hline $\mathbf{7}$ & Nad & 4 & 4 & 3 & 4 & 4 & 3 & 22 \\
\hline $\mathbf{8}$ & NAI & 4 & 4 & 4 & 4 & 4 & 4 & 24 \\
\hline $\mathbf{9}$ & PN & 4 & 3 & 4 & 4 & 4 & 4 & 23 \\
\hline $\mathbf{1 0}$ & SMS & 4 & 4 & 4 & 4 & 4 & 4 & 24 \\
\hline $\mathbf{1 1}$ & SS & 4 & 3 & 4 & 4 & 4 & 4 & 23 \\
\hline $\mathbf{1 2}$ & SPS & 4 & 3 & 4 & 4 & 3 & 3 & 21 \\
\hline $\mathbf{1 3}$ & YY & 4 & 4 & 4 & 4 & 4 & 4 & 24 \\
\hline $\mathbf{1 4}$ & YM & 4 & 4 & 3 & 4 & 4 & 4 & 23 \\
\hline & & Jumlah Keseluruhan & & & $\mathbf{3 0 6}$ \\
\hline & & Skor Maksimal & & & \\
\hline
\end{tabular}


Hasil uji praktikalitas respon peserta didik di SDN 22 Pasaman memperoleh persentase skor $91 \%$ dengan kategori sangat praktis. Produk dinyatakan praktis untuk digunakan di kelas IV SD.

Berikut perhitungan hasil praktikalitas angket repon peserta didik di SDN 26 Pasaman.

Tabel 6. Hasil Praktikalitas Respon Peserta Didik SDN 26 Pasaman

\begin{tabular}{|c|c|c|c|c|c|c|c|c|}
\hline \multirow[t]{2}{*}{ No } & \multirow[t]{2}{*}{ Responden } & \multicolumn{6}{|c|}{ Responden Terhadap Pertanyaan } & \multirow[t]{2}{*}{ Jumlah } \\
\hline & & 1 & 2 & 3 & 4 & 5 & 6 & \\
\hline 1 & $\mathrm{ARP}$ & 4 & 3 & 4 & 3 & 4 & 4 & 22 \\
\hline 2 & AIS & 4 & 4 & 3 & 4 & 4 & 4 & 23 \\
\hline 3 & $\mathrm{BFH}$ & 4 & 4 & 4 & 4 & 4 & 4 & 24 \\
\hline 4 & $\mathrm{CFP}$ & 4 & 3 & 3 & 4 & 3 & 3 & 20 \\
\hline 5 & DAP & 4 & 4 & 4 & 4 & 4 & 4 & 24 \\
\hline 6 & EAP & 4 & 4 & 4 & 4 & 4 & 4 & 24 \\
\hline 7 & FA & 4 & 4 & 4 & 4 & 4 & 4 & 24 \\
\hline 8 & GA & 4 & 4 & 4 & 4 & 4 & 4 & 24 \\
\hline 9 & GW & 4 & 4 & 4 & 3 & 3 & 3 & 21 \\
\hline 10 & IFP & 4 & 4 & 4 & 4 & 4 & 4 & 24 \\
\hline 11 & $\mathrm{KA}$ & 4 & 4 & 4 & 3 & 4 & 3 & 22 \\
\hline 12 & MAA & 4 & 4 & 4 & 4 & 4 & 4 & 24 \\
\hline 13 & MJ & 4 & 3 & 4 & 2 & 4 & 3 & 20 \\
\hline 14 & MFR & 4 & 4 & 4 & 3 & 3 & 3 & 21 \\
\hline 15 & NM & 4 & 3 & 4 & 2 & 4 & 3 & 20 \\
\hline 16 & OK & 4 & 3 & 4 & 3 & 4 & 4 & 22 \\
\hline 17 & $\mathrm{RF}$ & 4 & 4 & 4 & 4 & 4 & 4 & 24 \\
\hline \multicolumn{8}{|c|}{ Jumlah Keseluruhan } & 383 \\
\hline \multicolumn{8}{|c|}{ Skor Maksimal } & 408 \\
\hline
\end{tabular}

Hasil uji praktikalitas respon peserta didik di SDN 26 Pasaman memperoleh persentase skor $93,8 \%$ dengan kategori sangat praktis. Produk dinyatakan praktis untuk digunakan di kelas IV SD.

Produk yang diracang di validasi oleh masing-masing validator dan memperoleh masukan dan saran sehingga dilakukan perbaikan. Bagian yang dilakukan perbaikan dan tindakan yang peneliti lakukan terhdapat masukan dan saran dari vallidator di sajikan dalam tabel sebagai berikut.

Tabel 8. Revisi dari Validator

\begin{tabular}{ccc}
\hline Validator & Bagian yang perlu di revisi & Bagian yang telah di revisi \\
\hline Ahli Media & $\begin{array}{c}\text { Pengelompokan mata pelajaran } \\
\text { dengan indikator di halaman tujuan } \\
\text { diperjelas pengelompokannya }\end{array}$ & $\begin{array}{c}\text { Mata pelajaran dengan indikator } \\
\text { sudah diperjelas } \\
\text { pengelompokkannya }\end{array}$ \\
\cline { 2 - 3 } & $\begin{array}{c}\text { Pernyataan pembuka di awal } \\
\text { materi di beri audio agar lebih }\end{array}$ & $\begin{array}{c}\text { Pernyataan pembuka sudah di } \\
\text { beri audio }\end{array}$ \\
\hline
\end{tabular}




\begin{tabular}{|c|c|c|}
\hline \multicolumn{3}{|c|}{ menarik } \\
\hline & $\begin{array}{l}\text { Dialog pembuka, tanya jawab } \\
\text { materi, gambar peta, dan } \\
\text { penjelasan diberi audio }\end{array}$ & $\begin{array}{l}\text { Dialog pembuka, tanya jawab } \\
\text { materi, gambar peta, dan } \\
\text { penjelasan materi sudah di beri } \\
\text { audio }\end{array}$ \\
\hline & $\begin{array}{l}\text { Gambar yang bukan milik } \\
\text { pengembang dicantumkan } \\
\text { sumbernya }\end{array}$ & $\begin{array}{c}\text { Gambar sudah dicantumkan } \\
\text { sumbernya }\end{array}$ \\
\hline & $\begin{array}{l}\text { Gambar yang dipilih dengan } \\
\text { resolusi tinggi agar tidak pecah }\end{array}$ & $\begin{array}{c}\text { gambar sudah diganti dengan } \\
\text { yang beresolusi tinggi }\end{array}$ \\
\hline & $\begin{array}{c}\text { Space kosong disamping pertanyaan } \\
\text { di bagian evaluasi }\end{array}$ & $\begin{array}{c}\text { Desain soal evaluasi sudah di } \\
\text { perbaharui agar tidak ada space } \\
\text { kosong }\end{array}$ \\
\hline & $\begin{array}{c}\text { Informasi tindak lanjut dari soal } \\
\text { esai yang diberikan }\end{array}$ & $\begin{array}{l}\text { Sudah diberi informasi tindak } \\
\text { lanjut untuk pengerjaan soal essai }\end{array}$ \\
\hline \multirow[t]{2}{*}{ Ahli Materi } & $\begin{array}{c}\text { Memperhatikan tata tulis } \\
\text { menyesuaikan dengan karakteristik } \\
\text { siswa }\end{array}$ & $\begin{array}{c}\text { Tata tulis sudah diperbaiki sesuai } \\
\text { karakteristik siswa }\end{array}$ \\
\hline & $\begin{array}{c}\text { Warna yang dipakai lebih } \\
\text { dikontraskan dan ukuran tulisan } \\
\text { diperhatikan }\end{array}$ & $\begin{array}{l}\text { Warna sudah dikontraskan dan } \\
\text { ukuran tulisan sudah diperbaiki }\end{array}$ \\
\hline \multirow[t]{4}{*}{ Ahli Bahasa } & $\begin{array}{l}\text { Kata Hello Shuter di ganti dengan } \\
\text { kata filosofis }\end{array}$ & $\begin{array}{l}\text { Sudah di ganti dengan kata yang } \\
\text { filosofis (ayo belajar, mari belajar) }\end{array}$ \\
\hline & Menggunakan kata baku & $\begin{array}{l}\text { Sudah di ganti dengan kata yang } \\
\text { baku }\end{array}$ \\
\hline & $\begin{array}{l}\text { Gunakan huruf yang lebih besar } \\
\text { pada multichoice }\end{array}$ & $\begin{array}{l}\text { Huruf di multichoice sudah } \\
\text { diperbesar dari sebelumnya }\end{array}$ \\
\hline & $\begin{array}{c}\text { Tambahkan paragraf } 3 \text { dan } 4 \text { pada } \\
\text { soal essay }\end{array}$ & $\begin{array}{l}\text { Sudah ditambahkan paragraf } 3 \\
\text { dan } 4 \text { pada essay }\end{array}$ \\
\hline
\end{tabular}

\section{Pembahasan}

Penelitian dan pengembangan ini menghasilkan produk media pembelajaran Articulate Storyline menggunakan model Think Pair Share (TPS) pada tema 7 subtema 1 di kelas IV Sekolah Dasar. Menurut Jalinus dan Ambiyar (2016) media pembelajaran adalah mengenai perangkat keras dan lunak yang dapat digunakan untuk menyampaikan materi pembelajaran ke peserta didik yang dapat merangsang peserta didik dalam proses pembelajaran sehingga lebih efektif. Dalam penelitian ini mengembangkan media pembelajaran yang menggunakan perangkat lunak dan membuat peserta didik tertarik untuk mengikuti pembelajaran. Model pembelajaran yang digunakan yaitu model pembelajaran kelompok yaitu TPS. Reinita dan Andrika (2017) menyatakan bahwa hasil yang didapatkan dari menerapkan model ini ialah memaksimalkan hasil belajar peserta didik karena membuat peserta didik aktif dalam berpikir.

Darnawati, et., al. (2019) mengemukakan bahwa media pembelajaran menggunakan Articulate Storyline diharapkan mampu menjadi alternatif media pembelajaran yang dapat menghadirkan suasana pembelajaran baru dan menarik serta mampu membantu pendidik menyampaikan materi yang sulit disampaikan. Dalam penelitian ini menurut hasil angket yang diisi oleh guru dan peserta didik media pembelajaran Articulate Storyline ini memudahkan guru menyampaikan materi dan peserta didik tertarik belajar menggunakan media pembelajaran Articulate Storyline dan sangat membantu dalam memahami pembelajaran. 
Pengembangan media pembelajaran Articulate Storyline kurikulum 2013 berbasis kompetensi peserta didik abad 21 tema 7 kelas IV Sekolah Dasar oleh Arwanda, Irianto, dan Andriani (2020) memperoleh hasil yang sangat layak baik dari validator, respon guru dan respon peserta didik sehingga media pembelajaran ini dapat digunakan dalam proses pembelajaran. Media pembelajaran yang dikembangkan memiliki perbedaan dengan penelitian sebelumnya. Penelitian sebelumnya mengembangkan media pembelajaran Articulate Storyline yang berbasis kompetensi peserta didik abad 21 pada tema 7 subtema 1 pembelajaran 2, sedangkan media pembelajaran yang dikembangkan pada penelitian ini adalah media pembelajaran yang menggunakan model TPS dilakukan pada kelas IV tema 7 subtema 1 pembelajaran 3,4, dan 5. Penelitian pengembangan ini diharapkan berhasil seperti media pembelajaran yang dikembangkan oleh penelitian-penelitian sebelumnya.

\section{Simpulan}

Media pembelajaran Articulate Storyline sudah di uji kevalidannya oleh masingmasing ahli. validasi oleh ahli media dan ahli bahasa dilakukan sebanyak dua kali dan ahli materi dilakukan sebanyak satu kali. Untuk ahli media pada validasi pertama memperoleh $70,3 \%$ dengan kategori valid dan untuk validasi kedua memperoleh 76,5\%\% dengan kategori sangat valid. Untuk ahli materi memperoleh 91\% dengan kategori sangat valid. Untuk ahli bahasa pada validasi pertama memperoleh $75 \%$ dengan kategori valid dan pada validasi kedua memperoleh $100 \%$ dengan kategori sangat valid. Media pembelajaran Articulate Storyline yang dikembangkan memperoleh tingkat kevalidan dengan rentang kategori valid hingga sangat valid sehingga media pembelajaran Articulate Storyline dapat digunakan di lapangan.

Media pembelajaran Articulate Storyline juga dilihat tingkat kepraktisannya. Kepraktisan media pembelajaran Articulate Storyline dinilai oleh guru wali kelas dan peserta didik. Untuk kepraktisan respon guru SDN 22 Pasaman memperoleh tingkat kepraktisan 91,6\% dengan kategori sangat praktis dan tingkat kepraktisan SDN 26 Pasaman memperoleh 95,8\% dengan kategori sangat praktis. Kepraktisan dari respon peserta didik SDN 22 Pasaman memperoleh tingkat kepraktisan 91\% dengan kategori sangat praktis dan tingkat kepraktisan di SDN 26 Pasaman memperoleh $93,8 \%$ dengan kategori sangat praktis. Melihat hasil kepraktisan dari respon guru dan peserta didik terhadap media pembelajaran Articulate Storyline praktis untuk digunakan di kelas IV Sekolah Dasar.

\section{Saran}

Adapun saran pemanfataan produk sebagai berikut.

1. Bagi guru media pembelajaran Articulate Storyline ini dapat digunakan untuk meningkatkan minat belajar peserta didik sehingga peserta didik dapat dengan mudah menyerap informasi pembelajaran yang disajikan karena hasil uji coba kelayakan media ini menyatakan bahwa media pembelajara Articulate Storyline ini layak dan praktis digunakan dalam pembelajaran.

2. Hasil penelitian pengembangan media pembelajaran Articulate Storyline menggunakan model pembelajaran Think Pair Share (TPS) ini dapat membantu peserta didik untuk lebih aktif dalam pembelajaran dan dapat meningkatkan minat dalam belajar.

3. Saran untuk penggunaannya yaitu menggunakan alat berupa infokus untuk penayangannya dan juga adanya koneksi internet untuk menampilkan media pembelajaran. 
Adapun saran pengembangan produk lebih lanjut sebagai berikut.

1. Bagi semua pihak yang akan mengembangkan produk ini lebih lanjut bisa dengan cara menambahkan pengembangannya untuk 1 tema sehingga produk yang dihasilkan lebih menyeluruh karena produk ini hanya memuat pada tema 7 subtema 1 pembelajaran 3,4, dan 5 .

2. Produk yang dikembangkan selanjutnya dapat diakses oleh seluruh peserta didik dimana pun berada.

\section{Referensi}

Arwanda, P., Irianto, S., dan Andriani, A., (2020). Pengembangan Media Pembelajaran Articulate Storyline Kurikulum 2013 Berbasis Kompetensi Peserta Didik Abad 21 Tema 7 Kelas IV Sekolah Dasar. Jurnal Ilmiah Pendidikan Madrasah Ibtidaiyah, 4(2), 193-204.

Darnawati, Jamiludin, Batia, L., Irawaty, \& Salim. (2019). Pemberdayaan Guru Melalui Pengembangan Multimedia Pembelajaran Interaktif Dengan Aplikasi Articulate Storyline. Amal Ilmiah: Jurnal Pengabdian Kepada Masyarakat, 1(1), 8-16.

Fathurrohman, M. (2015). Model-Model Pembelajaran Inovatif. Yogyakarta: Ar-Ruzz Media

Hamzah, A. (2019). Metode Penelitian \& Pengembangan (Research \& Development):Uji Produk Kuantitatif dan Kualitatif Proses dan Hasil Dilengkapi Contoh Proposal Pengembangan Desain Uji Kualitatif dan Kuantitatif. Malang: CV Literasi Nusantara Abadi.

Jalinus, N dan Ambiyar. (2016). Media \& Sumber Pembelajaran. Jakarta: Kencana

Kustandi, C \& Sutjipto, B. (2011). Media Pembelajaran Manual dan Digital. Bogor: Ghalia Indonesia

Murti, O. S., \& Reinita, R. (2020). Pengaruh Model Kooperatif Tipe Think Pair Share terhadap Hasil Belajar Tematik Terpadu di Sekolah Dasar. Jurnal Pendidikan Tambusai, 4(3), 2147-2155.

Nabilah, C. H., Sesrita, A., dan Suherman, I. (2020). Development Of Learning Media Based On Articulate Storyline. Indonesian Journal of Applied Research (IJAR), 1(2), 80-85.

Peraturan Menteri Pendidikan dan Kebudayaan Nomor 22 Tahun 2016 tentang Standar Proses Pendidikan Dasar dan Menengah. Jakarta: Kemendikbud

Prahl, K. (2017). Best Practices for the Think-Pair-Share Active-Learning Technique. The American Biology Teacher, 79(1), 3-8.

Pratama, R. A. (2018). Media Pembelajaran Berbasis Articulate Storyline 2 Pada Materi Menggambar Grafik Fungsi Di Smp Patra Dharma 2 Balikpapan. Jurnal Dimensi, 7(1), 19-35.

Rafmana, H., Chotimah, U., dan Alfiandra. (2018). Pengembangan Multimedia Interaktif Berbasis Articulate Storyline Untuk Meningkatkan Motivasi Belajar Siswa Pada Mata Pelajaran PKn Kelas XI Di SMA Srijaya Negara Palembang. Jurnal Bhinneka Tunggal Ika, 5(1), 52-65.

Reinita, dan Andrika, D. (2017). Pengaruh Penggunaan Model Kooperatif Tipe Think Pair Share (TPS) dalam Pembelajaran Pkn di Sekolah Dasar. Jurnal Inovasi Pendidikan dan Pembelajaran Sekolah Dasar, 1(2), 61-73.

Rianto, R. (2020). Pembelajaran Interaktif Berbasis Articulate Storyline 3. Indonesian Language Education and Literature, 6(1), 84-92.

Rohmah, F. N., \& Bukhori, I. (2020). Pengembangan Media Pembelajaran Interaktif Mata Pelajaran Korespondensi Berbasis Android Menggunakan Articulate Storyline 3. Ecoducation: Economic and Education Journal, 2(2), 169-182.

U'la, I. D., Murtono, M., \& Ulya, H. (2018). Efektivitas Model Pembelajaran ThinkPair-Share (TPS) Terhadap Kemampuan Komunikasi Matematis Siswa. ANARGYA: Jurnal Ilmiah Pendidikan Matematika, 1(1), 51-58. 